Fall 12-20-2019

\title{
Development of a Financial Literacy Component for a Comprehensive Secondary Transition Program for Diploma-bound Students with Learning Differences
}

\author{
Rose Marie Borillo \\ University of St. Augustine for Health Sciences \\ DOI: https://doi.org/10.46409/sr.EOUY4396
}

Follow this and additional works at: https://soar.usa.edu/capstones

Part of the Finance and Financial Management Commons, Occupational Therapy Commons, and the Secondary Education Commons

\section{Recommended Citation}

Borillo, R. (2019). Development of a Financial Literacy Component for a Comprehensive Secondary

Transition Program for Diploma-bound Students with Learning Differences. [Doctoral project, University of St Augustine for Health Sciences]. SOAR @ USA: Student Capstone Projects Collection. https://doi.org/ $10.46409 /$ sr.EOUY4396

This Capstone is brought to you for free and open access by the Student Research at SOAR @ USA. It has been accepted for inclusion in Student Capstone Projects by an authorized administrator of SOAR @ USA. For more information, please contact soar@usa.edu, erobinson@usa.edu. 
DEVELOPMENT OF A FINANCIAL LITERACY COMPONENT FOR A COMPREHENSIVE SECONDARY TRANSITION PROGRAM

FOR DIPLOMA-BOUND STUDENTS WITH LEARNING DIFFERENCES

by

Rose Marie B. Borillo

A Capstone Presented in Partial Fulfillment

of the Requirement for the Degree of

DOCTOR OF OCCUPATIONAL THERAPY

University of St. Augustine for Health Sciences

December 2019 


\title{
DEVELOPMENT OF A FINANCIAL LITERACY COMPONENT FOR A COMPREHENSIVE SECONDARY TRANSITION PROGRAM \\ FOR DIPLOMA-BOUND STUDENTS WITH LEARNING DIFFERENCES
}

by

\author{
Rose Marie B. Borillo \\ has been approved
}

December 2019

APPROVED:

Susan MacDermott, OTD, OTR/L, Doctoral Coordinator

Becki Cohill, OTD, OTR/L, Doctoral Coordinator

Erin Schwier, EdD, OTD, OTR/L, Program Director

ACCEPTED AND SIGNED:

\begin{tabular}{|c|c|}
\hline $\begin{array}{l}\text { Susan MacDermott, } \\
\text { OTD, OTR/L }\end{array}$ & $\begin{array}{l}\text { Digitally signed by Susan } \\
\text { MacDermott, OTD, OTR/L } \\
\text { Date: } 2019.12 .1788: 45: 36-080^{\prime} 00^{\prime}\end{array}$ \\
\hline \multirow{2}{*}{\multicolumn{2}{|c|}{ 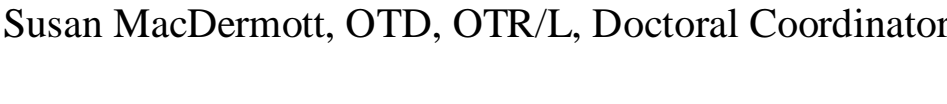 }} \\
\hline & \\
\hline $\begin{array}{r}\text { Becki Cohill, OTD, O } \\
\text { eschwier@usa }\end{array}$ & 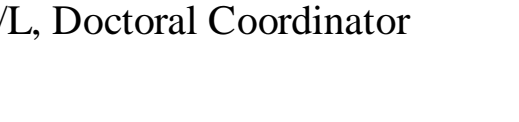 \\
\hline
\end{tabular}


Table of Contents

$\begin{array}{lc}\text { CHAPTER I: Introduction } & 5\end{array}$

Background $\quad 5$

Statement of the Problem $\quad 6$

$\begin{array}{ll}\text { Purpose Statement } & 6\end{array}$

Rationale for the Proposed Project

Significance of the Proposed Project 9

Preliminary Project Objectives 10

Assumptions, Limitations, Delimitations 10

Definitions $\quad 11$

CHAPTER II: Literature Review 13

Factors for Post-Secondary Success $\quad 13$

Components of Secondary Transition Planning 14

Role of Occupational Therapy in Secondary Transition Planning 17

$\begin{array}{ll}\text { CHAPTER III: Project Description } & 18\end{array}$

$\begin{array}{ll}\text { Participants } & 19\end{array}$

Materials 20

Design 21

Procedures and Timelines $\quad 24$

CHAPTER IV: Results and Analysis $\quad 25$

Focus Group $\quad 25$

$\begin{array}{ll}\text { Parent Interview } & 25\end{array}$

Budget Pre- and Post-Survey 26

Student Reflection Responses 28

CHAPTER V: Discussion and Conclusion $\quad 30$

Limitations 33

Recommendations for Further Research 33

Implications for Occupational Therapy Practice 35 
$\begin{array}{ll}\text { Conclusion } & 37\end{array}$

$\begin{array}{ll}\text { References } & 38\end{array}$

$\begin{array}{ll}\text { APPENDIX A } & 43\end{array}$

$\begin{array}{ll}\text { APPENDIX B } & 44\end{array}$

$\begin{array}{ll}\text { APPENDIX C } & 45\end{array}$

$\begin{array}{ll}\text { APPENDIX D } & 46\end{array}$

$\begin{array}{lc}\text { APPENDIX E } & 51\end{array}$ 


\section{CHAPTER I: Introduction}

\section{Background}

The Individuals with Disabilities Education Act (IDEA) requires schools to provide transition planning for students with disabilities and mental illness by age 16 (Berg, Jirikowic, Haerling, \& MacDonald, 2017; Eismann et al., 2017; Spencer, Sherman, Nielsen, \& Thormodson, 2018). Under IDEA, schools should implement an individualized education plan (IEP) that focuses on the child's specific needs and occupational therapy can serve as supplemental support (Eismann et al., 2017). The Winston School in Del Mar, California, is a "coeducational, college preparatory, independent day school" to support students with learning differences who otherwise would not thrive in a traditional school setting (The Winston School, 2019, para. 1). The student population at The Winston School consists of 115 students in grades 6 to 12 with various levels of needs. About $50 \%$ are publicly funded and the other $50 \%$ are private school students and all students require extra educational support due to learning differences such as attention deficit disorder (ADD), attention deficit-hyperactivity disorder (ADHD), autism spectrum disorder (ASD), and motor and sensory challenges (The Winston School, 2019). All of the publicly funded students have an IEP, but the private school students do not because IDEA only applies to federally funded students, however private school students are still able to receive transition planning without an IEP. For students with an IEP, they receive transition planning in the form of a college decision consultation with the Assistant Head of School. According to the School Accountability Report Card (SARC), about $40 \%$ of students receive occupational therapy to help with executive function skills such as organization and 
anxiety management in order to be successful in the classroom, however occupational therapy is not included in transition planning (The Winston School, 2019).

\section{Statement of the Problem}

Currently at Winston, there is no formal transition program for students however transition planning consists of a college decision consultation with the Assistant Head of School. This consultation does not include a plan that includes incorporating independent living skills, such as financial literacy, needed for a student to succeed after leaving Winston. Young people in the United States have demonstrated to have the lowest level of financial literacy and are considered one of the more vulnerable groups due to the need to make financial decisions related to debt (i.e. school loans, credit card) (Lusardi \& Wallace, 2013). A coordinated transition program is needed that can expand what is currently provided and can be integrated within the school curriculum to prepare students for life after Winston to include financial literacy, as well as career readiness, post-secondary education readiness, and independent living skills.

\section{Purpose Statement}

The purpose of this project is to develop the financial literacy component as a part of a coordinated, comprehensive transition program that addresses the specific skills and needs of diploma bound students with learning differences to transition into post-secondary education or work. 


\section{Rationale for the Proposed Project}

Occupational therapists can help adolescents in their transition into post-secondary education, and adulthood in general, through task analysis and environmental adaptations of occupations such as daily living, education, work, leisure, and community participation (Orentlicher et al., 2017). Many of the skills necessary for post-secondary educational success include self-determination (self-advocacy, self-awareness, motivation, and initiation) and selfregulation (Berg et al., 2017). Financial literacy has become a priority for Winston to address as it allows students to become more aware of money management to help navigate college applications, finding careers, and being able to support themselves financially. In helping students develop these skills within transition planning during high school, or even earlier, students may be able to find successful outcomes in college or with employment.

Using the life-span development model, occupational therapists acknowledge the multidimensional, multidirectional, and plasticity of development and use that knowledge to prepare students with their transition into adulthood (Landmark \& Geye, 2014). The performance patterns of an adolescent in high school shift as they enter college and adulthood with new roles and routines, especially when introduced to new contexts and environments. This interaction with the environment contributes to occupational development, which is described as a gradual change in occupational behavior over time, resulting from the growth and maturation of the individual (D’Entremont, Gregor, Kirou, Nelligan, \& Dennis, 2017).

Occupational therapists can also utilize the Person-Environment-Occupation Model (PEO) to consider an individual's contexts and environments to shape a transition program to 
support the person's wants and needs and improve occupational performance (Brown, 2014). The PEO model is a transactional model of occupational performance that examines the interdependence of the person and their environment and its influence on occupational performance (Law et al., 1996). The person includes intrinsic factors such as performance patterns and skills, life experience, and sensorimotor and cognitive abilities. The environment includes extrinsic factors such as cultural, socio-economic, institutional, physical and social contexts and environments. Occupation in the PEO model is defined as groups of self-directed functional tasks and activities (Law et al., 1996). In this case, students' financial literacy skills are impacted by their cognitive abilities, performance skills, performance patterns, and life experience. This in turn impacts their ability to engage in occupations such as education, social participation, and activities of daily living as many things have a financial component especially once they become more responsible for their independence. Environmental influences such as their cultural background, parent values, and the physical environment they live in impacts financial literacy. In addition, through this model, we can anticipate the dynamic changes in contexts and environments as students transition from high school to college to facilitate occupational performance and promote self-determination. The high school environment, especially one like The Winston School, has significant differences compared to the college, workplace, or community environments that students will be transitioning to. In the K-12 education, students have support from designated school staff to help them through navigating school support systems, however in college, that support may not be as readily available. Although through Section 504, individuals with disabilities or mental illness have a legal right to receive accommodations, these students would have to disclose their disability, however due to 
stigma, some students choose not to seek these services (Berg et al., 2017). With this shift in availability of resources as well as a different social environment hindering self-disclosure, a transition program can help students develop the self-determination skills to be successful.

\section{Significance of the Proposed Project}

Students at Winston are considered diploma-bound and able to obtain a traditional diploma by meeting the A-G requirements to attend a college or university. Existing transition programs for students with disabilities that are diploma-bound are primarily academically focused and lack the independent living skills to support their transition into adulthood. Although they may succeed academically, a comprehensive, coordinated transition program can help these individuals succeed with post-high school outcomes including financial literacy. Young people currently live in a society where money is "invisible" because of credit cards and are required to make financial decisions at earlier ages, leaving them vulnerable to the consequences of debt (Blue, Grootenboer, \& Brimble, 2014). Students will require knowledge about student or car loans, budgeting, credit cards, and financial decision making as a part of their transition to college, work, or living independently (Lusardi \& Wallace, 2013). A lack of financial planning and preparedness has been linked to greater rates of dropping out of college (Poynton, Lapan, \& Marcotte, 2015). A financial literacy program can help students develop a foundation for future financial behaviors and well-being (Beverly \& Burkhalter, 2005). Occupational therapists are able to tailor the curriculum to meet the students' specific learning needs and take consideration of environmental influences to optimize occupational performance and self-determination. In addition, success with this program can be shared with schools across the nation to support not 
only students with disabilities but including the general student population as well as to include occupational therapy as an integral component of transition planning and services.

\section{Preliminary Project Objectives}

The objectives of this project are to:

1. Identify barriers and supports to implementation of a comprehensive transition program

2. Assess the needs of the students through assessment tools to identify interests and skills needed to inform program development

3. Determine measurable outcomes based on expected learning outcomes for financial literacy

4. Develop the financial literacy component as part of a comprehensive transition program to be incorporated into the school-wide curriculum

Additional objectives to be considered in the future are to assess the outcomes of the transition program, assess the developed transition program at other schools, and advocate for occupational therapy in transition services.

\section{Assumptions, Limitations and Delimitations}

Assumptions. The project assumed that the students at the Winston School need a comprehensive transition program and require support in areas of college readiness, independent living skills, financial literacy, and community engagement. As evidenced in the literature, students with learning differences have expressed concerns in these areas and have benefited from some type of transition plan (Berg et al., 2017; Eismann et al., 2017). Another assumption 
is that the students want to or will be attending post-secondary education. It is also assumed that the students do not already have strong financial literacy skills. Financial literacy was identified by key stakeholders as an area to be included in the transition program.

Limitations. Since the Winston School is a specialized day school for students with learning differences, there may be services provided that are different from the traditional public school setting for students with IEP's, and therefore is not generalizable to the population outside of this school.

Delimitations. The scope of this project includes its application to a single school site in the San Diego Unified School District. The school has received a grant to support the transition program in which the grantors have specified the inclusion of financial literacy and career readiness. Areas of focus that are being considered are college readiness, career exploration, independent living skills, and community engagement, attributes that have been correlated with postsecondary education success (Berg et al., 2017; Hadley, 2012; Martinez, Baker, \& Young, 2017). The program, however, will also be tailored depending on the specific needs of the students within these areas of focus based on the assessments.

\section{Definitions}

\section{Diploma bound}

Students that are diploma bound receive a traditional diploma after completing the A-G certified courses (see Table 1), which are required for admission to a University of California or California State University school (San Diego Unified School District, n.d.). 
Table 1

\begin{tabular}{|cll|}
\hline Minimum A-G Requirements & \\
& & \\
\hline A & History/Social Science & 4 credits (2 years) \\
B & English & 8 credits (4 years) \\
C & Mathematics & 6 credits (3 years) \\
D & Laboratory Science & 4 credits (2 years) \\
E & Language Other Than English & 4 credits (2 years) \\
& (World Language) & \\
F & Visual and Performing Arts & 2 credits (1 year) \\
G & College Prep Electives & 2 credits (1 year) \\
\hline & & Total: 30 credits \\
\hline
\end{tabular}

\section{Self-determination}

Self-determination is associated with the characteristics of self-advocacy, self-awareness, motivation, and initiation, all of which are important for success in transitioning to postsecondary education (Berg et al., 2017). Self-determination can be defined by having the attitude and ability to making decisions for one's self without influence from others (Gragoudas, 2014).

\section{Independent living skills}

Independent living skills includes the ability to independently participate in occupations such as activities of daily living (ADLs) and instrumental activities of daily living (IADLs) as defined in the Occupational Therapy Practice Framework (OTPF) (American Occupational Therapy Association, 2014). Activities of daily living relevant to this population includes personal hygiene and grooming and sexual activity. Instrumental activities of daily living relevant to this population includes communication management, driving and community mobility, financial management, health management and maintenance, meal preparation and cleanup, safety and 
emergency maintenance, and shopping. The domain of occupational therapy also includes education, work, leisure, play, and social participation.

\section{College Readiness}

The four facets that are included in the conception of college readiness are key cognitive strategies, key content knowledge, academic behaviors, and contextual skills and knowledge (Conley, 2008). College readiness for Winston students also includes visiting various campuses, understanding the application process, and knowing how to navigate resources such as disabilities services.

\section{Financial Literacy}

According to the National Standards for Financial Literacy, the definition of financial literacy is having the knowledge, understanding, and skills important for decision making related to personal finance (Blue et al., 2014; Bosshardt \& Walstad, 2014). The Expected Learning Outcome for this area, as determined by The Winston School, includes being able to complete a personal budget, understanding credit, opening a checking and savings account, opening a retirement and/or investment account, understanding small business development, and basic accounting.

\section{CHAPTER II: Literature Review}

\section{Factors of Post-Secondary Success}

Self-determination, self-efficacy, and self-advocacy were described as factors of success for students with disabilities transitioning from high school to post-secondary education, 
employment, and community engagement (Berg et al., 2017; Gragoudas, 2014; Hadley, 2012; LaPorte, Haber, \& Malloy, 2016; White et al., 2017). Self-determination skills such as choice making, decision making, problem solving, and goal setting are demonstrated to be skills essential for students with disabilities to find and secure employment (Gragoudas, 2014). Students with intellectual and/or developmental disabilities in the exploratory case study by Berg et al. (2017), expressed they had difficulties with self-disclosure of their disability once at the college setting due to fear of stigma. Although, these students attended classes on self-advocacy, these skills still were not fully developed, indicating need to emphasize these particular skills.

Participation in community-based activities were perceived to be a strong predictor of successful transition outcomes as it demonstrates communication and social skills (Eismann et al., 2017). An example of a community-based program that demonstrated positive outcomes is from a study by Shea and Siu (2016) from the Occupational Therapy Training Program in San Francisco that implemented play activities to facilitate the acquisition of life skills for youth in detention ages 14-18. The researchers found that the use of play supported the students' development of self-efficacy, stress management, flexibility, intrinsic motivation, internal control, social competence, adaptability to change, and coping skills (Shea \& Siu, 2016).

\section{Components of Secondary Transition Planning}

In the literature, existing secondary transition programs focused on specific components rather than a comprehensive approach. The specific components identified for the purpose of this review includes financial literacy, college readiness, career planning, independent living skills, 
and community engagement. Some of these components have been combined in certain programs. These components also align with the four pillars determined by The Winston School: financial literacy, job readiness, college readiness, and life skills.

Financial literacy education is a priority component for The Winston School and has been identified as a global priority and a core life skill for everyone (Blue et al., 2014). Young people in the United States and other countries often display low levels of financial literacy which is a risk considering the financial decisions this population often have to face, such as student loans and buying a car (Lusardi \& Wallace, 2013). Standards have been developed by a group of economists and economic educators that were presented to the Council for Economic Education (Bosshardt \& Walstad, 2014). These six standards were established to provide the knowledge, understanding, and skills that are important for students to learn about personal finance and include the following: 1) earning an income, 2) buying goods and services, 3) saving, 4) using credit, 5) financial investing, and 6) protecting and insuring (Bosshardt \& Walstad, 2014). Although there are existing financial literacy programs, many of them are not suitable for students with disabilities due to its complexity and inability to address specific situations related to individuals with disabilities (Beverly \& Burkhalter, 2005). These existing programs will have to be adapted to the specific learning needs of the students at Winston. Educators will also require training and guidance to provide financial literacy education (Blue et al., 2014). These financial concepts provide contexts for students in setting personal goals, engaging in decisionmaking, participating in problem solving, and taking actions that serve their best interest, all of which are crucial for transition planning in preparation for adulthood (Henning \& Johnston- 
Rodriguez, 2018). Financial literacy can be incorporated in multiple classroom subjects including mathematics, science, and history.

College readiness and career planning are the most common components seen in transition programs that are available for all students, not just for students with an IEP. Winston currently provide college counseling with the assistant head of school but is looking to expand this component. Kline and Kurz (2014) provide a model of professional collaboration with a vocational rehabilitation program for transition planning which emphasizes active collaboration between the student and school personnel to increase successful post-secondary outcomes.

Independent life skills programs typically incorporate experiential learning opportunities to promote personal growth. In a study by King et al. (2019), a Residential Immersive Life Skills (RILS) program was implemented for youth with disabilities aged 14-21 to focus on preparation for adult roles. The activity settings focused on developing opportunities for cooperative group activity, social interaction with adults and peers, choice, and personal growth, which the researchers have identified as important for self-realization in adolescence and in preparation for adulthood (King et al., 2019). The findings of their study support the residential, immersive nature of a transition-support program to have enhanced effectiveness in increased likelihood of successful transitions of youth with disabilities to adulthood. The program studied by Swank and Huber (2013) focused on four initiatives that promoted work skills, life skills, and social and emotional development: a school vegetable garden, a raised worm bed, a sewing group, and community collaboration. By providing hands on experience to develop job skills using real life situations, students also learned social skills by working with classmates, and selfdetermination skills by identifying their personal interests and strengths (Swank \& Huber, 2013). 


\section{Role of Occupational Therapy in Secondary Transition Planning}

School-based occupational therapists have historically been underutilized in secondary transition planning despite being identified as a related service for special education through IDEA (Kardos, M. \& Prudhomme White, 2005; Mankey, 2012; Spencer, Emery, \& Schneck, 2003). Of the 41 participants surveyed in a study by Mankey (2012) in Arkansas, the majority of which were special education specialists, 40 of the participants shared that there was no involvement of occupational therapy in transition planning at their school. Reasons included having no knowledge or awareness of occupational therapy being involved (20\%), occupational therapy was not offered at the school (13\%), participants stated a lack of need for occupational therapy (35\%), and limited resources for occupational therapy (10\%) (Mankey, 2012). Even within the profession, occupational therapists had limited knowledge and experience in transition services, despite having the qualifications, skills, and resources (Kardos, \& Prudhomme White, 2005).

Occupational therapists are able to target functional abilities, comprehension, and health among students with disabilities in this transition period and provide many avenues for promoting skill attainment to achieve independence (Berg et al., 2017; Eismann et al., 2017). Through the fundamental use of activity analysis, occupational therapists analyze activities and occupations that people are engaged with to better understand and address the skills and external components for that person to be able to perform the activity (Thomas, 2015). Using the Occupational Practice Framework (OTPF), occupational therapists are able to analyze all aspects of the domain, including occupations, client factors, performance skills, performance patterns, and context and environment, and how each of those components contribute to an individual's 
ability to participate in activities (AOTA, 2014). In the systemic review by Spencer et al. (2018), evidence of occupational therapy interventions for students with mental illness transitioning to post-secondary education was examined that occupation-based, client-centered based programs were effective in addressing health management and maintenance, leisure, work, and social participation. Occupational therapists from a community-based program worked with students in a continuation high school that had difficulty with transitioning to post-secondary education and navigating a career path (Shea \& Giles, 2016). The therapists were able to help students explore occupational interests and set realistic and achievable goals through occupation-based interventions. As an outcome, students developed increased sense of self-efficacy that helped the individual transition into post-secondary education and pursuing careers. In the area of financial literacy, occupational therapists in a quasi-experimental pilot study have effectively used leisurebased activities as a means to help homeless adolescents acquire financial literacy skills (Schultz-Krohn et al., 2018). Financial management is within the domain of occupational therapy under instrumental activities of daily living (AOTA, 2014).

\section{CHAPTER III: Program Description}

The objectives of this capstone project are to complete a needs assessment regarding the strengths and barriers to developing a financial literacy program, assess the occupational needs of students, initiate the development of the financial literacy component, and create an outcome measure for program evaluation and student learning. Students, teachers, and parents provide valuable information to inform the development of a student-centered transition program on financial literacy. 


\section{Participants}

The Winston School has approximately 100 students, including both middle and high school. Initially, the focus was intended to include both the $11^{\text {th }}$ and $12^{\text {th }}$ graders, of which there are about 40 students. Instead, the students that participated were the ten $12^{\text {th }}$ grade students enrolled in the semester long College and Career Readiness class due to the accessibility of the students and their direct involvement in the program. Students in the class have specific learning disabilities, speech and language impairment, autism spectrum disorder, emotional disturbances, and other health impairments that impact their ability to learn in a traditional learning environment. The focus group was instead structured as a classroom activity to gather information regarding learning needs, goals, and level of knowledge regarding financial literacy from those enrolled students. Informal assessments on learning preferences and styles, personal qualities and characteristics, money values and habits were assigned as class assignments and were used to design the program.

All parents were to be sent an e-mail to participate in a voluntary survey, however, under the suggestion of the head of school, it was made as an assignment for students to interview their parents. Parents were surveyed by their students to gather information on personal or family values and expectations on financial literacy education for their children as well as to help families start the conversation about their student's personal financial management.

Informal interviews with teachers and classroom observation helped to gain perspective on the strengths and barriers at the school, what is effective with working with students, how to fit in financial literacy education within the existing curriculum and additional insight to the 
culture of the school. The transition team, which included the assistant head of school, teacher of record for the College and Career Readiness course, and the occupational therapy student, encouraged all teachers to collaborate and contribute to the overall transition program goals during the pre-service week prior to school starting. The occupational therapy student collaborated closely with the math and economics teachers to review their curriculum and identify areas in which their classes already discuss financial literacy topics as well as provide supplementary material based on the College and Career Readiness curriculum.

\section{Materials}

To guide the conversation in the focus group, a list of questions was curated to gather information pertinent for the program development of the financial literacy component (See Appendix A). Questions were based on existing questionnaires of financial literacy, money management, and life skills. Stemming from the PEO model, questions regarding intrinsic factors such as learning abilities, routines, life experience, and extrinsic factors such as cultural and social contexts will help guide development of the program and how information is presented to the students to optimize learning. Questions for the parents were centered on the values and culture relating to financial literacy to provide information on the students' extrinsic factors (see Appendix B). Teachers provided the context from the school perspective through informal conversations about their perceptions and experience.

Resources from existing evidence-based financial literacy programs, such as the Junior Achievement Finance Park curriculum, were reviewed to influence key topics and activities that can be tailored to the Winston School students. Other financial literacy sources were identified 
based on research by Henning and Johnston-Rodriguez (2018) for curricula suitable for students with learning disabilities. Curricula from the research included Practical Money Skills by Visa, Pathway to Financial Success by Discover, and Money Smart for Teens by FDIC. By analyzing the existing financial literacy curriculum and current course curriculum (i.e. mathematics, economics, etc.), a tailored program was created to meet the individualized needs of Winston students. Other resources and learning from other transition programs were identified to contribute to program development such as the National Alliance for Secondary Education and Transition (NASET), California Career Zone, and the Department of Rehabilitation.

Additionally, access to students' Individualized Education Plan (IEP) and academic surveys provided additional insight to specific needs in the classroom including overall strengths, student engagement, and overall progress. Those students with an IEP also have an Individualized Transition Plan (ITP) that included specific transition goals that could be addressed in the course such as researching colleges, creating a budget, and researching costs of apartments.

\section{Design}

The needs assessment was necessary to determine areas of deficit and proficiency in the area of financial literacy as well as preferred learning styles and goals. Using the PEO model, the first step includes identifying occupational strengths and difficulties in occupational performance, especially in the area of financial literacy skills. This includes assessing each component of the model such as performance components of the person (or population), environmental conditions, and occupation, activities, and tasks. To assess performance 
components, an assessment of learning styles and preferences provided insight into their strengths as learners. The focus group assessed identified needs or deficits regarding financial literacy and the impact on their self-efficacy and independence. Surveys from the parents regarding cultural values toward financial literacy is also an assessment of environmental impact. These activities translate to the greater idea of financial literacy and for the students to be able to make appropriate financial decisions but also overall decision making and self-efficacy. Since these students are preparing to transition to life after Winston, either pursuing post-secondary education or working at a job, they will need to develop forward-thinking skills to think about future financial decisions, such as student loans or purchasing a car. Using this information, the program was created to maximize occupational performance to meet the students where they are and to create meaningful connections to how financial literacy education can help them navigate the different environments they may encounter after Winston. Information gathered from the teachers and families provide perspectives from the students' environment and contexts of family, social, cultural, socio-economical, and institutional influences.

\section{Procedures and Timeline}

Due to unforeseen personnel changes at the Winston School, immediate in-depth curriculum development was prioritized over the initial needs assessment. Researching appropriate curriculum creating the scope and sequence were prioritized from week 1 to week 5 and week 7, respectively. The scope and sequence is the course outline that details the topics, objectives, and activities of each lesson for the semester. Classroom observation was limited as summer school was near the end and students had a little over two weeks off before the fall semester. Figure 1 provides a visual description of the timeline of objectives. 


\begin{tabular}{|c|c|c|c|c|c|c|c|c|c|c|c|c|c|c|c|c|c|}
\hline \multirow[b]{2}{*}{ TASKS } & \multicolumn{2}{|c|}{ July } & \multicolumn{3}{|c|}{ August } & \multicolumn{3}{|c|}{ September } & \multicolumn{4}{|c|}{ October } & \multicolumn{3}{|c|}{ November } & \multicolumn{2}{|c|}{ December } \\
\hline & 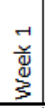 & 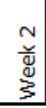 & 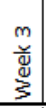 & 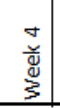 & $\begin{array}{l}n \\
\stackrel{n}{\dddot{m}} \\
\grave{3}\end{array}$ & 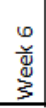 & 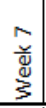 & 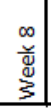 & 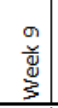 & 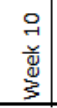 & $\begin{array}{l}\vec{I} \\
\stackrel{-}{\mathbb{d}} \\
\overrightarrow{3}\end{array}$ & 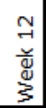 & 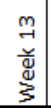 & $\begin{array}{l}\vec{J} \\
\stackrel{\vec{J}}{\mathbb{J}} \\
\overrightarrow{3}\end{array}$ & 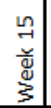 & 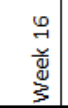 & 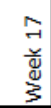 \\
\hline \multicolumn{18}{|l|}{ ASSESSMENTS } \\
\hline \multicolumn{18}{|l|}{ Classroom Observation } \\
\hline \multicolumn{18}{|l|}{ Focus group } \\
\hline \multicolumn{18}{|l|}{ Parent Interview } \\
\hline \multicolumn{18}{|l|}{ Budget Pre-Survey } \\
\hline \multicolumn{18}{|l|}{ Budget Post-Survey } \\
\hline \multicolumn{18}{|l|}{ Student Interviews } \\
\hline \multicolumn{18}{|l|}{ PROGRAM DEVELOPMENT } \\
\hline \multicolumn{18}{|l|}{ Research curriculum } \\
\hline \multicolumn{18}{|l|}{ Develop scope \& sequence } \\
\hline \multicolumn{18}{|l|}{ Create lesson plans } \\
\hline \multicolumn{18}{|l|}{ Facilitate Unit 1: Who Am I? } \\
\hline \multicolumn{18}{|c|}{ Facilitate Unit 2: Financial Literacy } \\
\hline \multicolumn{18}{|c|}{ Facilitate Unit 3: Post-Secondary Options } \\
\hline \multicolumn{18}{|l|}{ Revise lesson plans } \\
\hline Revise scope \& sequence & & & & & & & & & & & & & & & & & \\
\hline
\end{tabular}

Figure 1. This Gantt chart provides a visual of tasks completed throughout the duration of the capstone experience.

The first two weeks of the College and Career Readiness class consisted of the "Who am I" unit where students reflected on their values, learning styles, and strengths. Students used the information from their assignments to create a multimedia presentation about themselves. This information was then used for the development of the rest of the course curriculum. During first week of the financial literacy unit, the needs assessment was assigned as class work and the parent interview as homework. Since the lessons have already been created, modifications were made based on the results and feedback of the initial assessment. Curriculum development was concurrent with implementation and continued throughout the semester. Each lesson outline was 
created with student learning preferences and needs in mind as well as thorough activity analysis. Lessons were refined for future classes according to student feedback and response to the lesson presentations and activities. A pre- and post-survey was created for the first part of the financial literacy curriculum to assess student knowledge about budgeting. Development and implementation of the college and career unit also took place from weeks 10 through 13.

In addition to the College and Career Readiness course, the occupational therapy student was also involved in the Winston Corner, a student café where students can purchase snacks during break and retrieve pre-ordered lunches. Student council members volunteer their time during the ten-minute break to implement financial management and small business skills by tracking sales through an inventory sheet. There is one student that is paid to work at the Winston Corner during lunchtime through the Workability I grant that the occupational therapy student supervised and promoted pre-employment skills.

\section{CHAPTER IV: Results and Analysis}

\section{Focus Group}

All the students enrolled in the College and Career Readiness $(n=10)$ participated in the focus group classroom activity. Most students (70\%) stated they receive money on a regular basis through a combination of work, allowance, and other means, such as gifts. All the students $(100 \%)$ stated they have a bank account where they keep their money. Some students have a joint account with parents, and some have their own once they turned 18 years old, however, the parents were still the ones controlling the account. When given a chance to respond to specific financial terms such as income, budget, saving, banking, insurance, students had a general idea 
of what each term meant, however, there were some responses that demonstrated limited knowledge. Students shared what they want to learn about financial management. Their responses included budgeting, banking, insurance, credit, "all the essentials," and "everything." After the first part of the financial literacy unit, students were asked what additional information they wanted to learn about, and their responses included taxes (29\%), saving/investing (29\%), banking (14\%), credit (14\%), loans (7\%), and insurance (7\%) (See Figure 2).
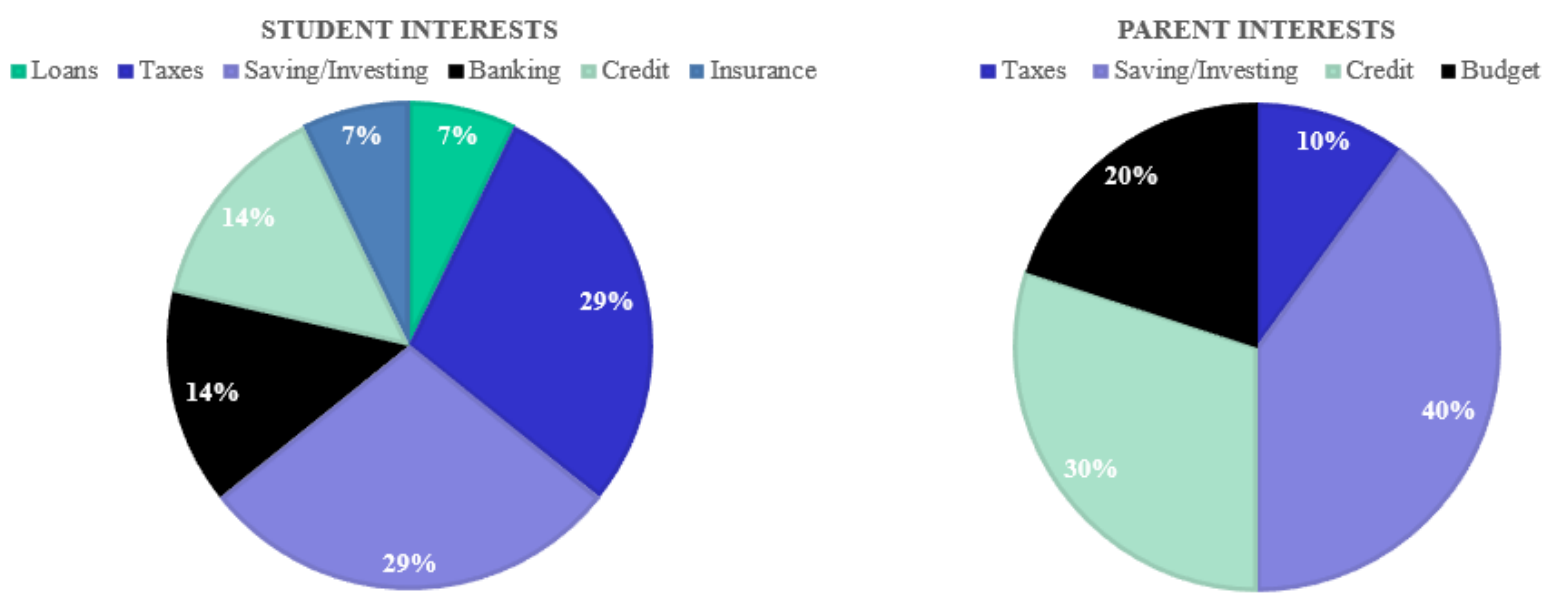

Figure 2. Summary of survey and interview results of students $(\mathrm{n}=10)$ and parents $(\mathrm{n}=10)$ and the financial literacy topics that were suggested to include in the program.

\section{Parent Interview}

The parent interview was presented as a homework assignment for students to initiate a conversation with their parents as well as to gather information. Out of the 10 parents surveyed, $80 \%$ indicated having a single-income household. More than half of the parents $(60 \%)$ utilize online services to manage their finances. When asked about how they learned about financial management, $90 \%$ indicated they were self-taught through personal experience. Topics they 
wished they learned when they were their child's age included budgeting (20\%), taxes (10\%), credit (30\%), and investing (40\%) as displayed in Figure 2.

\section{Pre- and Post-Survey}

Due to the scope and sequence of the class dividing the financial literacy component into two parts with the college and career unit in between, a pre- and post-survey was obtained with only the first part of the planned curriculum which was mainly budgeting. Students responded to a series of questions relating to budgeting using a 7-point Likert scale from strongly disagree to strongly agree. The post-survey was administered after the first part of the financial literacy lessons which covered financial habits, values, decision-making, and budgeting. For the postsurvey, a section was added to for the student to include a demonstration of knowledge as well as a one-on-one interview to gather for information and clarification of their responses. Students provided short-answer responses with specific examples of what they learned. Students provided feedback regarding their takeaways, what they liked about the lessons, what they would change, and additional topics they would like covered. Many of the students stated that being able to research and compare real costs for apartments, transportation, and groceries were helpful in bringing to light how much is required to spend for these necessary items. Some students expressed that they were surprised to see expensive certain items were, particularly rent, gas prices, home furnishing such as mattresses and couches. As for what to change, students suggested ideas to improve learning including spending more time on lessons and incorporating more hands-on activities. Table 2 highlights a few of the student responses from the interview.

\section{Table 2}


Student Interview Responses

\begin{tabular}{|c|c|c|}
\hline Key Take-Aways & What Students Liked & What to Change \\
\hline $\begin{array}{l}\text { - How to save for big } \\
\text { things (i.e. housing) } \\
\text { - How expensive the } \\
\text { cost of living is } \\
\text { - Didn't know how } \\
\text { expensive things were } \\
\text { - Some areas didn't } \\
\text { have transportation } \\
\text { - Multiple ways to save } \\
\text { money } \\
\text { - Understanding } \\
\text { budgeting (monthly \& } \\
\text { yearly) } \\
\text { - Understand prices of } \\
\text { food (i.e. eating at } \\
\text { home vs. eating out) } \\
\text { Be wise with money, } \\
\text { make every dollar } \\
\text { count }\end{array}$ & $\begin{array}{l}\text { Researching real costs } \\
\text { (housing, food, } \\
\text { transportation) } \\
\text { - Comparing different } \\
\text { prices (housing, food, } \\
\text { transportation) } \\
\text { - Liked being able to } \\
\text { choose apartments } \\
\text { and food prices } \\
\text { - Activities were } \\
\text { straightforward and } \\
\text { helped plan for the } \\
\text { future } \\
\text { - Comparing prices of } \\
\text { items from different } \\
\text { stores }\end{array}$ & $\begin{array}{l}\text { - Spend 1-2 days per } \\
\text { lesson to account for } \\
\text { processing time } \\
\text { - } \text { Cover different modes } \\
\text { of transportation than } \\
\text { just car and bus } \\
\text { - Include more food } \\
\text { categories in food } \\
\text { budget } \\
\text { - More hands-on } \\
\text { activity (like the bean } \\
\text { budget game) } \\
\text { - More group activities } \\
\text { - Use culinary kitchen } \\
\text { for food lesson }\end{array}$ \\
\hline
\end{tabular}

A comparison of the responses from the pre- and post-survey for the budget lessons are depicted in Figure 3. Overall, there was an increase in knowledge on budgeting especially in the following areas: understanding wants vs. needs; how to save money on a regular basis; understanding what a budget is and how to use it. Areas that were not as strong but still demonstrated improvement include calculating basic costs of living for a month; creating a monthly budget; and creating a yearly budget. 


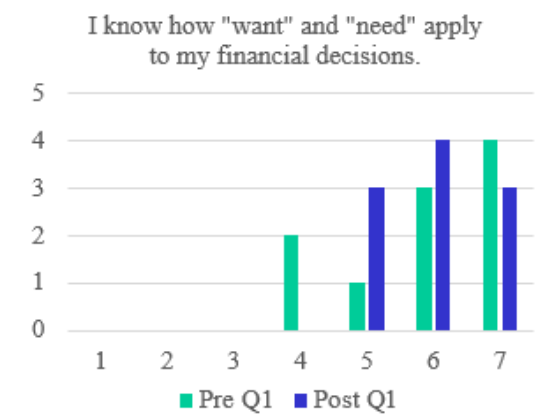

I can calculate basic costs of living for

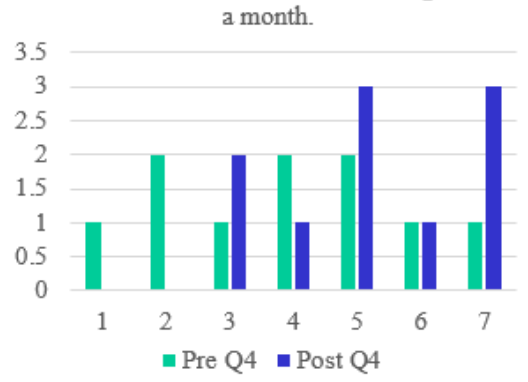

I know how to save money on a regular basis.

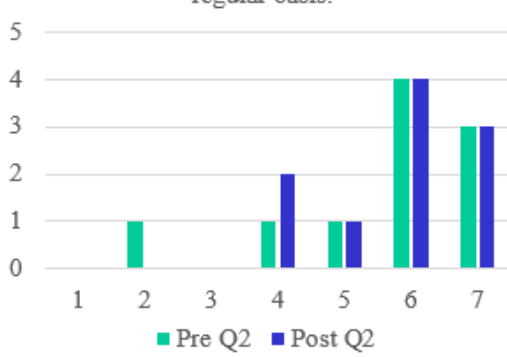

I can estimate basic costs of living for a year.

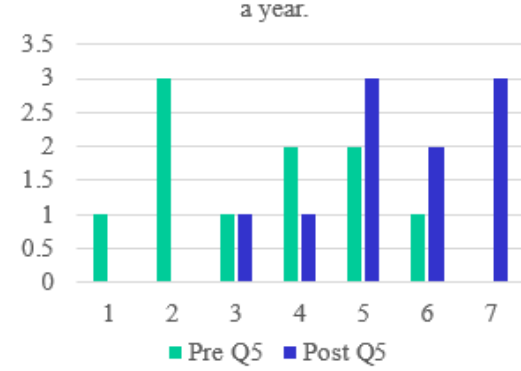

I understand what a budget is and how to use it.

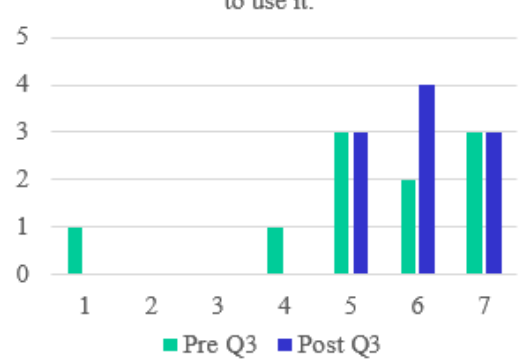

I can make a monthly budget.

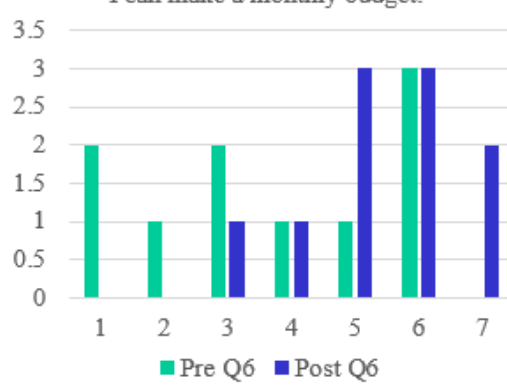

Figure 3. Comparison of the Budget Pre- and Post-Survey results $(\mathrm{n}=10)$ indicating an increase in knowledge on budgeting.

\section{Student Reflection Responses}

At the conclusion of the financial literacy unit, the students were assigned a reflection exit ticket where they provided feedback on what they enjoyed as well as things they would change about the lessons. The responses in Table 3 were pulled from the reflection assignment that students completed on the last day of the unit. The students were responding to lessons from the second part of the financial literacy unit which included taxes, banking, savings, investing, debit cards, credit cards, and credit score. The students were asked to provide a three to five sentence response with specific examples to the following prompts: Something I found useful was and why; Something I still want to know and why; Something I would do differently and why. The students found the comparison activities useful where they compared financial 
institutions, savings applications, health insurance policies, and credit cards. Some suggestions to do differently includes more emphasis on describing good and bad financial decisions based on those comparisons and opportunities to hear from a variety of perspectives regarding financial management.

Table 3

Student Reflection Responses

\begin{tabular}{|c|c|}
\hline What Students Found Useful & $\begin{array}{l}\text { What Students Suggested to Do Differently/ } \\
\text { Still Want to Know }\end{array}$ \\
\hline $\begin{array}{l}\text { - } \text { Comparing credit cards } \\
\text { - Understanding difference between } \\
\text { credit and debit cards } \\
\text { - Writing checks } \\
\text { - Credit score } \\
\text { - } \text { Debt due to poor financial decisions } \\
\text { - Comparing medical insurance plans } \\
\text { - } \text { Difference between FDIC \& NCUA } \\
\text { insured financial institutions } \\
\text { - } \text { Research banks/credit unions } \\
\text { - } \text { Different ways to save money } \\
\text { - } \text { Budgeting to prevent } \\
\text { - } \text { Interspending/impulsive spending } \\
\text { process }\end{array}$ & $\begin{array}{l}\text { - } \text { Simulation at Winston Corner } \\
\text { - } \text { More freedom in choosing what credit } \\
\text { - } \text { Focus more on financial implications } \\
\text { from the research activities } \\
\text { - Include good and bad decision making } \\
\text { - Group work was slow-paced, prefer } \\
\text { - } \text { Provindependent activities } \\
\text { how other people might deal with } \\
\text { - } \text { Interviews with a variety of people to } \\
\text { - } \text { get more perspectives } \\
\text { - Timing and saving for retirement } \\
\text { decisions } \\
\text { Process of getting health insurance }\end{array}$ \\
\hline
\end{tabular}

\section{CHAPTER V: Discussion}

The Winston School had components of transition in various classes, particularly in English where students worked on resumes. When the development of a comprehensive 
transition program was proposed, the school decided to start with an elective course called College and Career Readiness. It this within this class that the financial literacy lessons would be included. During the pre-service meetings, the transition team including the occupational therapy student presented to the staff regarding the transition program. During that time, staff and faculty were asked about their definition of transition and how it relates to their role in the school. Many of the participants explained that transition was preparation for life after Winston through selfsufficiency, pre-employment skills, and college preparedness.

With the changes in staffing for the transition program, the occupational therapy student was able to contribute to the program in curriculum development through an occupational therapy lens. Not only did the occupational therapy student help with the financial literacy component, but also contributed to the other units as well. A completed scope and sequence, which is an outline of the anticipated class topics, objectives, and lesson outlines, was expected and created prior to the start of the new school year.

Overall, program development initially created through research and refined through trial and error based on students' responses to the lesson content, presentation, and assignments. The Winston School incorporates universal accommodations such as additional time on assignments and tests, access to assistive technology, and all assignments to be available electronically. The College and Career Readiness class utilizes multiple learning and instructing modalities, such as use of visuals (written directions, images, videos), audio (verbal instruction, listening to music with headphones), and tactile/kinesthetic (hands-on activities, moving around the classroom), to accommodate for the various student needs and preferences. The learning platform the students at the Winston School utilized is a called Unified Classroom which utilized both Google Drive 
and Microsoft OneDrive cloud services. Digital worksheets were created for each lesson to allow students to utilize whatever assistive technology is required for their learning such as speech-totext, text magnification, and spell-check. Presentation slides were also created to prove visual directions and examples as well as any supplementary audio-visual media to enhance learning.

The biggest barrier for the lessons was addressing the various processing skills of each student and finding an appropriate pace and structure. To rectify this, the revised lessons include activity gradations to grade up or "challenge" and to grade down or "simplify" an activity based on student needs. Many of the "simplify" suggestions were to complete activities as a class to accommodate for comprehension, reading, multi-step tasks, and pacing. In many cases, it was individual students that required to modify their assignments as well as one-on-one assistance from either the teacher, occupational therapy student, or other related service providers present in the room. As for the students who completed assignments more quickly were given "challenge" assignments to either research an additional item or write a reflection on what they learned.

The resulting program that was developed included 20 lessons on financial literacy to be covered over six weeks. Preceding the financial literacy unit was the first unit on self-discovery which included self-assessment of personal qualities, values, learning styles, and goals, all of which contributed to the rest of the curriculum as a person-driven, person-centered class. The AOTA Occupational Profile influenced the type of questions to guide self-exploration for the students to identify their strengths, goals, influences, and barriers (AOTA, 2014). Each lesson was meant to be relevant and meaningful to the individual as much as possible. Many of the assessments were included as in-class assignments. Class observations and feedback provided 
the major source of modifications and adaptations necessary to meet the students' learning needs and goals.

In addition to creating lesson plans, involvement with the Winston Corner, a student café run by student council volunteers and hired student employees through the Workability I grant, was another opportunity to support financial management and pre-employment skills. During the snack break, student council volunteers manage the money transactions and selling of food and drink items. There was no system of tracking money raised from the snack sales. A portion of the sales was supposed to support student council activities and the other portion were to go toward school wide events. An inventory system was created for students to tally which items have been sold. At the end of the week, the students and the student council advisor added the expected totals and reconcile it with the money raised in the till. Involving students in experiential learning opportunities such as this supports financial management, small business, and pre-employment skills (Keenan, King, Curran, \& Mcpherson, 2014). The students hired to work during lunchtime do not handle money transactions but instead focus more on the aspect of being organized, providing customer service, and completing tasks as stated in their job description in a timely manner. The student is responsible for setting up, distributing meals, and cleaning up.

\section{Limitations}

The limitations of this capstone project were mainly because the focus was on a small, specific population that is not representative of the greater population of students with learning 
differences. The project focused on primarily ten $12^{\text {th }}$ graders at a small non-public school in Del Mar, California. Program development was specific to these individual students and curriculum will need to be tailored further for future classes. Further research is recommended to expand outreach to other grade levels as well as other schools.

\section{Recommendations for Further Research}

Since the program was being developed and implemented simultaneously, there was a lot to gain from the experience. Changes were made in real-time to accommodate student needs and the lessons were revised to reflect those changes. The students that participated in the class provided insightful feedback in their reflection assignments regarding what they learned, what they want to learn, and suggestions on what should be changed. Overall, students shared that they thought the class was helpful and useful in introducing life skills topics to prepare them not just for college and career readiness but general independent living. A revised scope and sequence was created based on observations from this initial implementation and student feedback (See Appendix D).

Suggestions for the transition program moving forward is to follow a new scope and sequence that logically flows from understanding client factors and performance patterns and then proceeding with topics for post-secondary success. This can be through self-reflection assignments or informal assessments. This initial unit is essentially developing the student's occupational profile through identifying strengths, barriers, environmental and contextual influences, and goals. The next step would be identifying strengths as it relates to a career. Depending on the career or trade, a further examination into the education required would be the 
next focus. The unit of post-secondary options is meant to be broad depending on the needs of the students as they may not all be looking at four-year universities. Having more than one facilitator would make this process easier as the class can be grouped depending on their goals.

Since the focus of this project was to develop the financial literacy component, suggestions for this unit is more detailed. Due to certain college deadlines during the pilot program, the financial literacy unit was divided into two sections, three weeks before and after the post-secondary options unit. This undoubtedly was confusing for the students and their feedback was to keep all lessons in one unit. The first part of the financial literacy unit focused on identifying financial habits, values, goals as well as budgeting. During the pilot program, many of the lessons had to shift around because of some lessons requiring extra time for students to work on assignments.

After piloting the scope and sequence for the College and Career Readiness class, a comprehensive pre- and post-assessment was created as means to continue program evaluation and assess student learning (See Appendix E). When creating the pre- and post-assessments for the class, principles of Know-Want to know-Learned (KWL), a teaching strategy, was used to help the facilitator/teacher retrieve information as well as a self-reflection of what the students already know, what they want to know, and their goals (National Education Association, 2019). It is proposed to administer Section 1 on Post-Secondary Education and Jobs/Career before unit 1 and after unit 2, and Section 2 on Financial Management and Independent Living Skills before unit 3 and after unit 4.

\section{Implications for Occupational Therapy Practice}


There were academic standards to meet in addition to providing essential life skills to encourage success for college and career readiness. After much deliberation, it became clear that occupation-based activity analysis should be the basis for creating lesson plans. Although, many of the lessons were derived and adapted from existing curricula, what made it unique was through modifications to support individual learning needs and personalization through relevancy and addressing specific personal goals. Modifications were based on performance skills, such as motor, process, and social interaction skills, required to complete certain tasks like saving for the future, filing income task, and finding a place to live (Thomas, 2015).

As a part of activity analysis, it was important to complete the activity yourself to see what types of processing skills were required, how long the activity would take, and whether the directions were clear (Thomas, 2015). Classes are typically 45 to 50 minutes long in which you are to cover important content as well as a hands-on activity. This process is not unlike intervention planning for individual clients. The OTPF provided a basis of incorporating occupational therapy principles into curriculum development. The College and Career Readiness class utilized a "create, promote" approach as it provided "enriched contextual and activity experiences" to enhance performance for all people (AOTA, 2014). All students, regardless of ability or diagnosis, would benefit from taking this course to prepare them for the college, career, and independent living. Each of the lessons utilized a "establish, restore" approach to establish skills and abilities that have not yet developed especially in the areas of financial literacy (AOTA, 2014). Activity analysis was a key component of ensuring each lesson was carried out to meet the individual and group learning needs and preferences. Specific skills such as planning for the future, managing savings, and filing income tax are tasks that require higher level 
cognitive functions that vary across students (Thomas, 2015). Integrating graded modifications into the lesson plan will allow for the facilitator to accommodate for those differences. When deciding what topics to include, a combination of the National Standards of Financial Literacy, results from student and parent surveys, and research from financial literacy curriculum specific to students with learning disabilities were taken into consideration. Some financial topics require advanced critical thinking skills which may not be present in a typical teenager, let alone one with learning disabilities (Henning \& Johnston-Rodriguez, 2018). Therefore, topics such as investing were briefly touched upon and more time was spent on importance of saving, including comparison of savings accounts and mobile applications to facilitate appropriate decisionmaking skills and habits.

In addition to activity analysis, curriculum development utilized aspects of universal design for learning (UDL). Similar to universal design in architecture, the principles of UDL also include "equal access, flexibility, simplicity, perceptibility, and efficiency to both the educational environment and to the process of teaching and learning" (Henning \& Johnston-Rodriguez, 2018). Occupational therapists can provide consultation services to educators and administrator to promote and enhance student learning in the classroom (AOTA, 2015). This was observed at the Winston School where the Certified Occupational Therapist Assistant (COTA) and Speech Language Pathologist collaborated with the science teacher to incorporate a binder system to provide a method of organization to support students. Prior to their consultation, students struggled keeping up with the challenging material.

\section{Conclusion}


The Winston School's College and Career Readiness course is one piece of the comprehensive transition program. To continue the development of the class beyond financial literacy, focus on developing the college/career and life skills lessons is the next step. With the use of occupational-based activity analysis and principles of universal design for learning, curriculum development for financial literacy resulted in meaningful, experiential learning opportunities with appropriate modifications to meet student learning needs and preferences. School-based occupational therapists can expand their role in the classroom in supporting students to develop the necessary skills to prepare them for independent living. 


\section{References}

American Occupational Therapy Association. (2014). Occupational therapy practice framework: Domain and process (3rd Edition). American Journal of Occupational Therapy, 68(Supplement_1), S1. https://doi.org/10.5014/ajot.2014.682006

American Occupational Therapy Association. (2015). Fact sheet: Occupational therapy and universal design [pdf]. Retrieved from https://www.aota.org/ /media/Corporate/Files/AboutOT/Professionals/WhatIsOT/CY/FactSheets/UDL\%20fact\%20sheet.pdf

Berg, L. A., Jirikowic, T., Haerling, K., \& MacDonald, G. (2017). Navigating the hidden curriculum of higher education for postsecondary students with intellectual disabilities. American Journal of Occupational Therapy, 71(3), 71031000201-71031000209.

Beverly, S. G., \& Burkhalter, E. K. (2005). Improving the financial literacy and practices of youths. Children and Schools, 27(2), 121-124. https://doi.org/10.1093/cs/27.2.121

Blue, L., Grootenboer, P., \& Brimble, M. (2014). Financial literacy education in the curriculum: Making the grade or missing the mark? International Review of Economics Education, 16(PA), 51-62. https://doi.org/10.1016/j.iree.2014.07.005

Bosshardt, W., \& Walstad, W. B. (2014). National standards for financial literacy: Rationale and content. Journal of Economic Education, 45(1), 63-70.

https://doi.org/10.1080/00220485.2014.859963

Conley, D. T. (2008). Rethinking college readiness. New Directions for Higher Education, (144), 
3-13. https://doi.org/10.1002/he.321

D’Entremont, L., Gregor, M., Kirou, E., Nelligan, L., \& Dennis, D. (2017). Developmental milestones for productivity occupations in children and youth: An integrative review. Work, 56(1), 75-89. https://doi.org/10.3233/WOR-162466

Eismann, M. M., Weisshaar, R., Capretta, C., Cleary, D. S., Kirby, A. V., \& Persch, A. C. (2017). Characteristics of students receiving occupational therapy services in transition and factors related to postsecondary success. American Journal of Occupational Therapy, 71(3), 1-10. https://doi.org/10.5014/ajot.2017.024927

Gragoudas, S. (2014). Preparing students with disabilities to transition from school to work through self-determination training. Work, 48(3), 407-411. https://doi.org/10.3233/WOR131782

Hadley, W. (Western M. U. (2012). Students with learning disabilities transitioning from college: A one-year study. College Student Journal, (Ld), 421-430.

Henning, M. B., \& Johnston-Rodriguez, S. (2018). Evaluating financial literacy curriculum for young adults with special needs: A review of content, universal design for learning, and culturally responsive curriculum principles. Citizenship, Social and Economics Education, 17(2), 118-135. https://doi.org/10.1177/2047173418789593

Kardos, M. \& Prudhomme White, B. (2005). The role of the school-based occupational therapist in secondary education transition. American Journal of Occupational Therapy, 59(2), 173180. https://doi.org/10.5014/ajot.59.2.173 
Keenan, S., King, G., Curran, C. J., \& Mcpherson, A. (2014). Effectiveness of experiential life skills coaching for youth with a disability. Physical \& Occupational Therapy In Pediatrics, 34(2), 119-131. https://doi.org/10.3109/01942638.2013.842200

King, G., Mcpherson, A., Mosleh, D., Hartman, L., Rapley, J., \& Pinto, M. (2019). Program opportunities of residential immersive life skills programs for youth with disabilities. Research in Developmental Disabilities, 83, 233-246. https://doi.org/10.1016/j.ridd.2018.09.003

Landmark, L. J., \& Geye, T. (2014). Adolescence: A period of transition. Journal of the American Academy of Special Education Professionals, 107-122. Retrieved from https://files.eric.ed.gov/fulltext/EJ1135115.pdf

LaPorte, T. M., Haber, M. G., \& Malloy, J. M. (2016). Wraparound team composition, youth self-determination, and youth satisfaction in transition services. Journal of Behavioral Health Services and Research, 43(4), 611-629. https://doi.org/10.1007/s11414-014-9434-7

Law, M., Cooper, B., Strong, S., Stewart, D., Rigby, P., \& Letts, L. (1996). The PersonEnvironment-Occupation Model: A transactive approach to occupational performance. Canadian Journal of Occupational Therapy, 63(1), 9-23.

Lusardi, A., \& Wallace, D. (2013). Financial literacy and quantitative reasoning in the high school and college classroom. Numeracy, 6(2). https://doi.org/10.5038/1936-4660.6.2.1

Mankey, T. (2012). Educators' perceived role of occupational therapy in secondary transition. Journal of Occupational Therapy, Schools, and Early Intervention, 5(2), 105-113. 
https://doi.org/10.1080/19411243.2012.701974

Martinez, R. R., Baker, S. B., \& Young, T. (2017). Promoting career and college readiness, aspirations, and self-efficacy: Curriculum field test. Career Development Quarterly, 65(2), 173-188. https://doi.org/10.1002/cdq.12090

Orentlicher, M. L., Case, D., Podvey, M. C., Myers, C. T., Rudd, L. Q., \& Schoonover, J. (2017). Frequently Asked Questions (FAQ): What is occupational therapy's role in transition services and planning? Retrieved from https://www.aota.org/ /media/corporate/files/secure/practice/children/faq-what-is-ots-rolein-transition-services-and-planning-20170530.pdf

National Education Association. (2019). K-W-L: Know, Want to Know, Learn. Retrieved from http://www.nea.org/tools/k-w-l-know-want-to-know-learned.html

Poynton, T. A., Lapan, R. T., \& Marcotte, A. M. (2015). Financial planning strategies of high school seniors: Removing barriers to career success. Career Development Quarterly, 63(1), 57-73. https://doi.org/10.1002/j.2161-0045.2015.00095.x

Schultz-Krohn, W., Ang-Asuncion, I., Carter, K., Cone, J., Crane, L., Eduvala, L., \& Entrekin, K. (2018). Promoting financial literacy in homeless teens through a leisure-based occupational therapy program. American Journal of Occupational Therapy, 72(4_Supplement_1), 7211515267p1. https://doi.org/10.5014/ajot.2018.72S1-PO6022

Shea, C.-K., \& Giles, G. M. (2016). Goals and expectations of continuation high school students transitioning to postsecondary education. The Open Journal of Occupational Therapy, 4(4). 
https://doi.org/10.15453/2168-6408.1237

Shea, C. K., \& Siu, A. M. H. (2016). Engagement in play activities as a means for youth in detention to acquire life skills. Occupational Therapy International, 23(3), 276-286. https://doi.org/10.1002/oti.1432

Spencer, B., Sherman, L., Nielsen, S., \& Thormodson, K. (2018). Effectiveness of occupational therapy interventions for students with mental illness transitioning to higher education: A systematic review. Occupational Therapy in Mental Health, 34(2), 151-164. https://doi.org/10.1080/0164212X.2017.1380559

Spencer, J. E., Emery, L. J., \& Schneck, C. M. (2003). Occupational therapy in transitioning adolescents to post-secondary activities. American Journal of Occupational Therapy, 57(4), 435-441. https://doi.org/10.5014/ajot.57.4.435

Swank, J. M., \& Huber, P. (2013). Employment preparation and life skill development initiatives for high school students with emotional and behavioral disabilities. The Professional Counselor, 3(2), 73-81. https://doi.org/10.15241/jms.3.2.73

White, S. W., Elias, R., Capriola-Hall, N. N., Smith, I. C., Conner, C. M., Asselin, S. B., ... Mazefsky, C. A. (2017). Development of a college transition and support program for students with autism spectrum disorder. Journal of Autism and Developmental Disorders, 47(10), 3072-3078. https://doi.org/10.1007/s10803-017-3236-8 


\section{Appendix A}

\section{Questions for Student Focus Group on Financial Literacy}

1. Do you earn/receive money on a regular basis? Yes/No

2. If you answered "yes" in the previous question, how do you earn/receive money?

3. Where do you keep your money?
a. In a money box
b. In my pocket
c. In my wallet or purse
d. In a bank account
e. My parent/guardian keeps it
f. Other

4. If you were given $\$ 10,000$, what would you do with that money and why?

5. Where do you see yourself in 5 years? How about 10 years? (i.e. priorities and goals)

6. What does financial literacy mean to you?

7. What comes to mind when you hear the following words:
a. Income
b. Budget
c. Saving
d. Banking
e. Innsurance

8. Why do you think it is important to learn about finances?

9. What are some things about finance and money management that you want to learn about?

10. What would interest or motivate you to learn about finance/money?

11. Is there anything else you want to say about finance or money? 


\section{Appendix B}

\section{Parent Interview Questions}

This interview is intended to open the conversation about personal financial management to support your student in developing the skills necessary to become an independent adult. All responses are anonymous and are to be used to statistical purposes only.

1. How many incomes provide to the household?
a. Single income
b. Dual income
c. Other

2. What types of bills are paid and how often?

3. How do you keep track of payments and balances?

4. Do you use any apps or services to help manage finances?
a. If yes, what do you use?

5. Where did you learn about personal finance or money management?
a. Parent/Guardian
b. Relatives
c. School (primary or secondary)
d. School (post-secondary)
e. Self-taught - Personal Experience
f. Self-taught-Online
g. Other

6. How do you value money? Rank the following categories that you identify with from most (1) to least (5).
a. Security: You value money for the security it provides.
b. Status: You use money to make you feel important.
c. Self-indulgent: You want a lot of stuff and you want it now.
d. Self-fulfillment: Money itself is unimportant to you, however the importance is how it helps you get the things you need and want.
e. Not concerned: You are not concerned about money; there is no reason to worry about it.

7. What is something you wish you knew about personal finance or money management when you were my age? 


\section{Appendix C \\ Budget Pre- and Post-Survey}

Statements are rated on a 7-point Likert scale $(1=$ Strongly Disagree, $7=$ Strongly Agree $)$. To justify their scoring, students were required to provide examples of their knowledge. Following the post-survey, one-on-one interviews with the students took place to gain further information and clarification regarding their responses and to gather additional feedback.

1. I know how "want" and "need" apply to my financial decisions.

a. Provide an example of a "want" and a "need"

2. I know how to save money on a regular basis.

a. Provide an example of how to save money.

3. I understand what a budget it and how to use it.

a. Provide an example of a budget and how to use it.

4. I can calculate basic costs of living for a month.

a. Provide an example of monthly costs of living (ex: housing, transportation, food)

5. I can estimate basic costs of living for a year.

6. I can make a monthly budget.

a. Provide an example of monthly expenses.

7. I can make a yearly budget.

a. Provide an example of annual (yearly expenses)

8. Is there anything about budgeting and money management that was not addressed that you still want to learn about?

9. Describe 2 things you liked about this unit and 1 thing you would change. 


\section{Appendix D}

\section{Proposed College and Career Readiness Scope and Sequence}

The following scope and sequence is created specifically for the Fall Semester and has been modified from the piloted scope and sequence based on student feedback and response to lessons. For additional information or to see the lesson outlines in detail, please contact the author.

\begin{tabular}{|c|c|c|}
\hline Month & Topics Covered & Activities \\
\hline \multicolumn{3}{|c|}{ Unit 1: Who am I? (2 weeks) } \\
\hline \multirow[t]{5}{*}{ August } & Class Overview & $\begin{array}{l}\text { - Review of class syllabus and expectations } \\
\text { - Ice breaker bingo }\end{array}$ \\
\hline & A Day in a Life & $\begin{array}{l}\text { Write out your daily routine from waking up to } \\
\text { going to sleep } \\
\text { - What are your identified roles? Routines? Habits? }\end{array}$ \\
\hline & $\begin{array}{l}\text { Strengths, qualities, } \\
\text { characteristics, values }\end{array}$ & $\begin{array}{l}\text { - Personal strengths and values self-assessment and } \\
\text { reflection paragraph }\end{array}$ \\
\hline & $\begin{array}{l}\text { Learning Styles and } \\
\text { Preferences }\end{array}$ & $\begin{array}{l}\text { - Learning styles assessment } \\
\text { - Group brainstorm and share out }\end{array}$ \\
\hline & Goal Setting & $\begin{array}{l}\text { - Long term vs short term - can be personal, } \\
\text { academic, financial, career } \\
\text { - SMART goal format }\end{array}$ \\
\hline September & Me, Myself, and I Project & $\begin{array}{l}\text { - Multimedia presentation based on topics covered } \\
\text { from unit } 1\end{array}$ \\
\hline \multicolumn{3}{|c|}{ Unit 2: Exploring Post-High School Options (6 weeks) } \\
\hline \multirow[t]{2}{*}{ September } & Unit 2 Pre-Survey & \\
\hline & Work Preferences & $\begin{array}{l}\text { - Take the CA Career Zone Interest Profiler. Identify } \\
3 \text { jobs from the list that you might consider. }\end{array}$ \\
\hline
\end{tabular}




\begin{tabular}{|c|c|c|}
\hline & $\begin{array}{l}\text { What Employers Look } \\
\text { For }\end{array}$ & $\begin{array}{l}\text { Brainstorm what you think employers look for. } \\
\text { Complete a checklist of skills and attributes you } \\
\text { have or need to work on. }\end{array}$ \\
\hline & Elevator Speech & $\begin{array}{l}\text { - Create a } 30 \text { second elevator speech and present it } \\
\text { to the class. }\end{array}$ \\
\hline \multirow[t]{13}{*}{ October } & Applying for jobs & $\begin{array}{l}\text { - Where to look for jobs. } \\
\text { - Fill out a practice job application. }\end{array}$ \\
\hline & $\begin{array}{l}\text { How to Write a } \\
\text { Resume/Cover Letter }\end{array}$ & $\begin{array}{l}\text { - Gather pertinent information for the resume with } \\
\text { help from a parent. Create a resume and cover } \\
\text { letter. }\end{array}$ \\
\hline & Interviewing Success & $\begin{array}{l}\text { - } \quad \text { Tips for interviewing } \\
\text { - } \quad \text { Practice panel interview }\end{array}$ \\
\hline & $\begin{array}{l}\text { Reasonable } \\
\text { Accommodations }\end{array}$ & $\begin{array}{l}\text { - } \quad \text { Research using JAN } \\
\text { - } \quad \text { Share out findings }\end{array}$ \\
\hline & When and How to Quit & $\begin{array}{l}\text { Practice role playing appropriate ways of letting } \\
\text { your employer know that you are leaving the job. }\end{array}$ \\
\hline & Picking a Major & $\begin{array}{l}\text { - Use interest profile from CA Career Zone and look } \\
\text { at min. } 3 \text { colleges with that major }\end{array}$ \\
\hline & $\begin{array}{l}\text { What to Expect at a } \\
\text { College }\end{array}$ & $\begin{array}{l}\text { - Review differences between high school and } \\
\text { college }\end{array}$ \\
\hline & $\begin{array}{l}\text { Creating a Course } \\
\text { Schedule }\end{array}$ & $\begin{array}{l}\text { - Understanding GE requirements. } \\
\text { Use a course catalog to build a course schedule. } \\
\text { Include other activities to incorporate time } \\
\text { management. }\end{array}$ \\
\hline & College syllabi & $\begin{array}{l}\text { - Review examples of college syllabi and write a } \\
\text { reflection }\end{array}$ \\
\hline & $\begin{array}{l}\text { Learning Support } \\
\text { Services }\end{array}$ & $\begin{array}{l}\text { - Scavenger hunt for information on a school's } \\
\text { learning support (aka disability support) services } \\
\text { or programs. }\end{array}$ \\
\hline & College Resources & $\begin{array}{l}\text { - Scavenger hunt on college website to look up } \\
\text { different resources available }\end{array}$ \\
\hline & Paying for School & $\begin{array}{l}\text { - Financial aid, loans, grants, and scholarship } \\
\text { options }\end{array}$ \\
\hline & $\begin{array}{l}\text { Post-Secondary Options } \\
\text { Project }\end{array}$ & $\begin{array}{l}\text { Multimedia presentation on either a job/career or } \\
\text { college using the information from this unit }\end{array}$ \\
\hline
\end{tabular}




\begin{tabular}{|c|c|c|}
\hline & $\begin{array}{l}\text { Unit } 2 \text { Post-Survey \& } \\
\text { Reflection }\end{array}$ & \\
\hline OPTIONAL & $\begin{array}{l}\text { Guest Presenters \& Field } \\
\text { Trips }\end{array}$ & $\begin{array}{l}\text { - } \text { Department of Rehabilitation } \\
\text { - } \text { College representatives } \\
\text { - } \text { Business owners with disabilities } \\
\text { Campus site visit }\end{array}$ \\
\hline \multicolumn{3}{|c|}{ Unit 3: Financial Literacy (6 weeks) } \\
\hline \multirow[t]{8}{*}{ October } & Unit 3 Pre-Survey & \\
\hline & Money Values \& Habits & $\begin{array}{l}\text { - Self-assessment on money values } \\
\text { - Reflection and discussion }\end{array}$ \\
\hline & $\begin{array}{l}\text { Financial Decision } \\
\text { Making }\end{array}$ & - Decision making process guide \\
\hline & Financial Goals & - Vision board of financial goals and action plan \\
\hline & Income & $\begin{array}{l}\text { - Gross vs net income - taxes and deductions } \\
\text { - Looking at paycheck stub and understanding the } \\
\text { W-4 }\end{array}$ \\
\hline & Taxes & $\begin{array}{l}\text { - Understanding taxes } \\
\text { - Using a W-2 to fill out a } 1040 \text { form }\end{array}$ \\
\hline & Banking & $\begin{array}{l}\text { - } \quad \text { Bank vs Credit Union } \\
\text { - Compare financial institutions using a guide. Share } \\
\text { with the class and discuss which you would choose }\end{array}$ \\
\hline & Saving & $\begin{array}{l}\text { - Types of savings accounts } \\
\text { - Research savings apps } \\
\text { - Long term investments and retirement savings }\end{array}$ \\
\hline \multirow[t]{4}{*}{ November } & Credit & $\begin{array}{l}\text { - Looking at a credit card statement } \\
\text { - How to compare credit card offers } \\
\text { - Understanding your credit score and credit report }\end{array}$ \\
\hline & Insurance & $\begin{array}{l}\text { - Types of insurance matching activity } \\
\text { - Research and compare different health insurance } \\
\text { plans }\end{array}$ \\
\hline & Smart Shopping & $\begin{array}{l}\text { - Understanding needs vs wants } \\
\text { - Comparison shopping activity }\end{array}$ \\
\hline & Budgeting Basics & $\begin{array}{l}\text { - } \quad \text { Bean Budget activity } \\
\text { - } \quad \text { Create a monthly budget }\end{array}$ \\
\hline
\end{tabular}




\begin{tabular}{|c|c|c|}
\hline & Housing Budget & $\begin{array}{l}\text { - } \quad \text { Research cost of renting an apartment } \\
\text { - Where and how to search } \\
\text { - Understanding utilities and amenities } \\
\text { - Research cost of furnishing an apartment }\end{array}$ \\
\hline & Transportation Budget & $\begin{array}{l}\text { - Review cost of operating and maintaining a car } \\
\text { - Compare to the cost of taking public } \\
\text { transportation }\end{array}$ \\
\hline & Food Budget & $\begin{array}{l}\text { - } \quad \text { Meal planning activity } \\
\text { - } \quad \text { Create a shopping list } \\
\text { - } \quad \text { Research food prices }\end{array}$ \\
\hline & Vacation Budget Project & $\begin{array}{l}\text { - Pick a place to travel and try to budget for } \\
\text { transportation, lodging, food, and activities } \\
\text { - Present to the class as if you are a travel agent }\end{array}$ \\
\hline & $\begin{array}{l}\text { Unit } 3 \text { Post-Survey \& } \\
\text { Reflection }\end{array}$ & \\
\hline OPTIONAL & $\begin{array}{l}\text { Guest Presenters \& Field } \\
\text { Trips }\end{array}$ & $\begin{array}{l}\text { - Local bank or credit union (field trip and/or } \\
\text { presenter) } \\
\text { - Financial advisor } \\
\text { - Tax preparer } \\
\text { - Grocery store }\end{array}$ \\
\hline
\end{tabular}

Unit 4: Life Skills (4 weeks)

\begin{tabular}{|c|c|c|}
\hline \multirow[t]{6}{*}{ December } & Unit 4 Pre-Survey & \\
\hline & Self-care & - Personal hygiene \\
\hline & Importance of Sleep & $\begin{array}{l}\text { - Sleep hygiene: preparation for sleep, benefits of } \\
\text { sleep }\end{array}$ \\
\hline & Living with a Roommate & $\begin{array}{l}\text { - Personal boundaries, chores, cleanliness, shared } \\
\text { spaces } \\
\text { - Role playing: If your roommate is doing } \\
\text { something you don't like, how do you respond? }\end{array}$ \\
\hline & Home Management & $\begin{array}{l}\text { - } \quad \text { Basic home repairs } \\
\text { - Where to go or who to call when you need } \\
\text { something fixed }\end{array}$ \\
\hline & Food and Nutrition & $\begin{array}{l}\text { - Different options for where to get food } \\
\text { - Basics on how to prepare food }\end{array}$ \\
\hline
\end{tabular}




\begin{tabular}{|c|c|}
\hline Health Management & $\begin{array}{l}\text { - What to do when you are sick (where to go and } \\
\text { who to notify) }\end{array}$ \\
\hline Medication management & $\begin{array}{l}\text { - Pill organizers, apps, and other strategies } \\
\text { - What to do when travelling } \\
\text { - Food and other drug interactions }\end{array}$ \\
\hline Community Mapping & - Knowing what is in your community \\
\hline Time Management & $\begin{array}{l}\text { Different ways to manage your time and finding } \\
\text { technique that works for you }\end{array}$ \\
\hline Interpersonal Skills & $\begin{array}{l}\text { - Interacting with others: proximity, verbal } \\
\text { language, body language }\end{array}$ \\
\hline $\begin{array}{l}\text { Positive Recreation \& } \\
\text { Leisure }\end{array}$ & - What to do during unstructured time \\
\hline Stress Management & $\begin{array}{l}\text { - Being able to work with others you may not get } \\
\text { along with }\end{array}$ \\
\hline Conflict Resolution & $\begin{array}{l}\text { - Being able to work with others you may not get } \\
\text { along with }\end{array}$ \\
\hline \multicolumn{2}{|l|}{$\begin{array}{l}\text { Unit } 4 \text { Post-Survey \& } \\
\text { Reflection }\end{array}$} \\
\hline $\begin{array}{l}\text { Guest Presenters \& Field } \\
\text { Trips }\end{array}$ & $\begin{array}{l}\text { - Occupational Therapy (COTA) } \\
\text { - } \quad \text { Speech Therapy (SLP) } \\
\text { - } \quad \text { Counseling (Counselors) } \\
\text { - } \quad \text { Culinary class }\end{array}$ \\
\hline
\end{tabular}




\section{Appendix E \\ Proposed Comprehensive Pre- and Post-Assessment}

The following informal assessment is intended to help the facilitator or teacher gather information about the students' current knowledge on a topic, topics they are interested in learning about, and goals. The students will rate their knowledge on a Likert scale from 1 to 7 (1 $=$ Not knowledge about, $7=$ Very knowledgeable about). During the post-assessment, students will indicate what they learned after the unit has been completed as a self-reflection to reinforce learning. Section 1 is to be administered before Unit 1 and after Unit 2; likewise, Section 2 is to be completed before Unit 3 and after Unit 4. Additional responses to students to provide examples may be included to justify or clarify the rating of their knowledge.

\section{Section 1: College/Career Readiness}

\section{Post-Secondary Education}

Pre-Assessment:

- What do you already know about post-secondary education?

- On a scale from 1-7, how do you rate your knowledge on:

- Applying to college/school

- Choosing a major

- Paying for college/school

- Attending college/vocational classes

- Accessing support and resources in your program

- What do you want to know about post-secondary education?

- What is your goal for post-secondary education?

Post-Assessment:

- What did you learn about post-secondary education?

- On a scale from 1-7, how do you rate your knowledge on:

- Applying to college/school

- Choosing a major

- Paying for college/school

- Attending college/vocational classes

- Accessing support and resources in your program

- Is there anything you still want to learn about?

- Has your goal for post-secondary education changed? If so, what is your new goal? 


\section{Jobs/Career}

Pre-Assessment:

- What do you already know about jobs/careers?

- On a scale from 1-7, how do you rate your knowledge on:

- Finding a job

- Applying for jobs

- Creating a resume

- Creating a cover letter

- Interviewing for a job

- What do you want to know about jobs/careers?

- What is your goal for a job or career?

Post-Assessment:

- What did you learn about jobs/career?

- On a scale from 1-7, how do you rate your knowledge on:

- Finding a job

- Applying for jobs

- Creating a resume

- Creating a cover letter

- Interviewing for a job

- Is there anything you still want to learn about?

- Has your goal for jobs/career changed? If so, what is your new goal?

\section{Section 2: Life Skills}

\section{Financial Management}

Pre-Assessment:

- What do you already know about financial management?

- On a scale from 1-7, how do you rate your knowledge on:

- Budgeting

- Saving/Investing

- Insurance/Risk Management

- Credit

- Taxes

- What do you want to know about financial management? 
- What is your goal for financial management or a financial goal?

Post-Assessment:

- What did you learn about financial management?

- On a scale from 1-7, how do you rate your knowledge on:

- Budgeting

- Saving/Investing

- Insurance/Risk Management

- Credit

- Taxes

- Is there anything you still want to learn about?

- Has your goal for financial management changed? If so, what is your new goal?

\section{Independent Living Skills}

Pre-Assessment:

- What do you already know about independent living skills?

- On a scale from 1-7, how do you rate your knowledge on:

- Self-care and personal hygiene

- Finding a place to live

- Getting around in the community

- Buying groceries

- How to access health services

- What do you want to know about independent living skills?

- What is your goal for independent living?

Post-Assessment:

- What did you learn about independent living?

- On a scale from 1-7, how do you rate your knowledge on:

- Self-care and personal hygiene

- Finding a place to live

- Getting around in the community

- Buying groceries

- How to access health services

- Is there anything you still want to learn about?

- Has your goal for independent living changed? If so, what is your new goal? 